\title{
A STUDY OF ETIOLOGICAL AND CLINICAL PROFILE OF ACUTE SYMPTOMATIC SEIZURES IN ADULTS
}

\begin{tabular}{ll} 
Dr. Anbazhagan. G & $\begin{array}{l}\text { Department Of General Medicine, Meenakshi Medical College And } \\
\text { Research Institute, Enathur Kancheepuram, Chennai. }\end{array}$ \\
\hline Dr. Vibuja E.* & $\begin{array}{l}\text { Department Of General Medicine, Meenakshi Medical College And Research } \\
\text { Institute, Enathur Kancheepuram, Chennai. *Corresponding Author }\end{array}$ \\
\hline Dr. Sarika N. Holla & $\begin{array}{l}\text { Department Of General Medicine, Meenakshi Medical College And } \\
\text { Research Institute, Enathur Kancheepuram, Chennai. }\end{array}$ \\
\hline $\begin{array}{l}\text { Dr. Chakradhar } \\
\text { Arepalli }\end{array}$ & $\begin{array}{l}\text { Department Of General Medicine, Meenakshi Medical College And } \\
\text { Research Institute, Enathur Kancheepuram, Chennai. }\end{array}$ \\
\hline
\end{tabular}

\section{KEYWORDS :}

\section{INTRODUCTION}

The word seizure is derived from Latin word "Sacire" meaning 'to take possession of'. Seizure disorders are found Epilepsy can be broadly divided into idiopathic and symptomatic disorders. Idiopathic epilepsies are not associated with brain lesions or neurological abnormalities. They tend to be self limited and often respond well to antiepileptic therapy.An acute symptomatic seizure was defined in a recent recommendation from the International League Against Epilepsy (ILAE) as a clinical seizure occurring in close temporal relationship with an acute central nervous system insult which may be metabolic, toxic, infectious or inflammatory Seizures are common disorders found all over the that may require urgent attention and treatment to reverse world and are encountered frequently during medical potentially damaging causes. Such seizures are practice in variety of settings. Annually approximately considered to be an acute manifestation of the insult and 150,000 adults will present with a first seizure in the may not recur when the underlying cause has been United State ${ }^{1}$. India is home to about 10 million people removed or the acute phase has elapsed. The knowledge with epilepsy (prevalence of about $1 \%)$. An epileptic of the etiologic risk factors of acute symptomatic seizures seizure is an episode of neurologic dysfunction in which in third-world countries will invariably contribute to the abnormal neuronal firing is manifest clinically by changes effort aimed at preventing and managing medical conditions frequently complicated by seizures. The differential diagnosis of a single seizure includes psychogenic non-epileptic events, cardiac and neurogenic syncope, transient ischemic attacks, sleep disorders, and panic attacks.

\section{AIM OF THE STUDY}

1) To study the etiological profile of acute symptomatic seizures in various age groups,

2) To assess the common seizure type in patients with acute symptomatic seizures of varied etiologies

3) To study the Electro Encephalographic and Radiological profile of Acute symptomatic seizures.

\section{METHODS AND MATERIALS}

The study was done in the setting of the department of General medicine, Meenakshi Medical College and Research Institute, Kanchipuram, and the study was designed to analyse all adult patients who are more than 16 years of age in whom the specific cause for seizure could be identified. Sample size 150 and study period lyear.
The study was approved by the institutional ethical committee and carried out in a tertiary care hospital

\section{INCLUSION CRITERIA}

All adult patients who presented with acute seizures in whom the specific cause for seizure could be identified

\section{EXCLUSION CRITERIA}

1. Age less than 16 year

2. Known epileptic patients

3. Patients with family history of seizure

Each patient was explained about study and written informed consent was taken. A detailed history was taken from all patients and eyewitness. All patients were clinically evaluated and thorough clinical examination was done as per protocol. Each patient was subjected to hematological, biochemical and radiological investigations. Depending upon the suspected etiology, patients also underwent certain specific investigations were done. A CT scan of the head was done in all patients. The scan was performed without and with injection of contrast material. EEG was not available on an urgent basis hence it was performed in the inter-ictal period on an elective basis within the first 48 hours since a seizure. MRI was done in all patients where CT scan was non-diagnostic or inconclusive.

\section{RESULTS}

In this study 150 patients were evaluated clinically and using EEG and Neuro imaging In this study 86 were males and 64 female Male preponderance more in this study than compared to female.Common age group affected 40-60 next affected age group 20-40.Seizure type classifed in this study generalized $65 \%$ and partial $23 \%$

\section{BASED ON SEX}

\begin{tabular}{|l|l|l|}
\hline SEX & NUMBER & PERCENTAGE \\
\hline MALE & 86 & $57.3 \%$ \\
\hline FEMALE & 64 & $42.75 \%$ \\
\hline
\end{tabular}

BASED ON AGE

\begin{tabular}{|l|l|l|}
\hline AGE GROUP & NO & PERCENTAGE \\
\hline $13-20$ & 8 & $51 \%$ \\
\hline $21-40$ & 47 & $31 \%$ \\
\hline $41-60$ & 54 & $36 \%$ \\
\hline $61-80$ & 37 & $26 \%$ \\
\hline$>80$ & 4 & $2 \%$ \\
\hline
\end{tabular}

GJRA - GLOBAL JOURNAL FOR RESEARCH ANALYSIS 65 


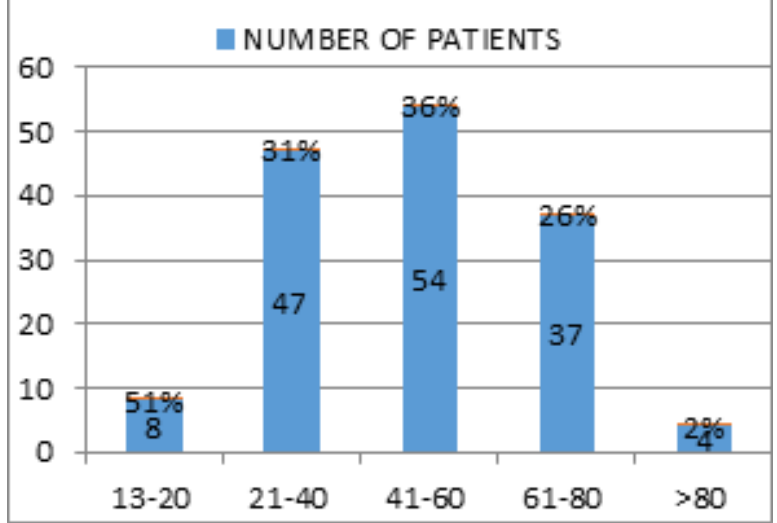

Head ache, vomiting, altered sensorium are the other non convulsive symptoms Headache presented in $68 \%$ of cases while altered sensorium in $43 \%$ of cases. Previous history of Diabetes was present in 14 patients and Hypertension present in 24patients.Metabolic abnormalities contributed to etiology in $13 \%$ of patients. The common abnormalities were Hyperglycemia and Hypoglycemia.

\section{NO OF PATIENTS}

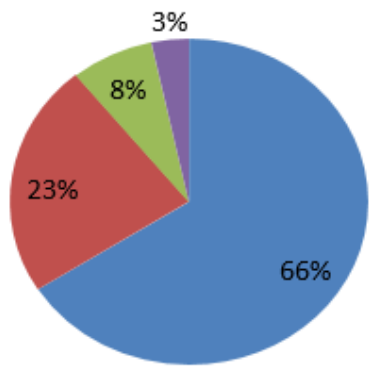

\section{FREQUENCY}

ALTERED SENSORIUM

VISUAL DISTURBANCES

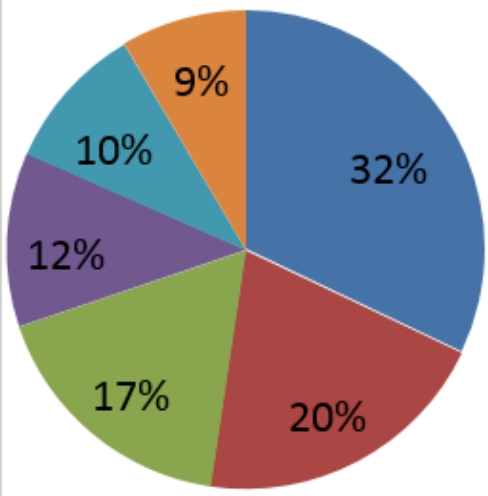

BASED ON SEIZURE TYPE

\begin{tabular}{|l|l|l|}
\hline SEIZURE TYPE & NO OF PATIENTS & PERCENTAGE \\
\hline GTCS & 97 & $65 \%$ \\
\hline FOCAL & 34 & $23 \%$ \\
\hline STATUS EPILEPTICUS & 11 & $7 \%$ \\
\hline EPC & 5 & $5 \%$ \\
\hline
\end{tabular}

BASSED ON COEXISTENT NON-CONVULSIVE SYMPTOM

\begin{tabular}{|l|l|}
\hline SYMPTOMS & FREQUENCY \\
\hline HEADACHE & $68 \%$ \\
\hline ALTERED SENSORIUM & $43 \%$ \\
\hline VOMITTING & $37 \%$ \\
\hline FEVER & $25 \%$ \\
\hline VISUAL DISTURBANCES & $21 \%$ \\
\hline LIMB WEAKNESS & $18 \%$ \\
\hline
\end{tabular}

In this study also patients having keto acidosis Blood sugar $>450$ exhibited high incidence of seizures and the sodium was found to be below 115 in hyponatremic patients.EEG was done in $114(76 \%)$ patients in the study. Abnormalities were found in $92(81 \%)$ of the EEGs done.

The yield of abnormalities in the EEG in this study could have been better if it were done more early or special methods such as continuous EEGs.The most common abnormality in EEG was sharp \& spike waves and poly spike activity. CT scan was done in all patients. When CT was inconclusive in revealing the lesion MRI was done. Imaging abnormalities contributed to the etiologies in $52 \%$ of patients. CT revealed abnormalities in 31 out of 36 and the rest of the 5 cases. 3 cases of Cortical venous thrombosis and 2 cases of Ischaemic stroke were revealed by MRI. Also in Neurocysticercosis inconclusive findings in the CT were revealed by MRI in 8 patients. HISTORY SUGGESTIVE OF ORGANICITY

\begin{tabular}{|l|l|}
\hline ORGANICITY & PERCENTAGE \\
\hline Post ictal confusion & $67 \%$ \\
\hline Frothing of saliva & $54 \%$ \\
\hline Bladder bowel & $15 \%$ \\
incontinence & $5 \%$ \\
Tongue biting & $5 \%$ \\
\hline Body injuries & $4 \%$ \\
\hline
\end{tabular}

PROFILE OF SIGNIFICANT PAST HISTORY

\begin{tabular}{|l|l|}
\hline PAST MEDICAL HISTORY & NO OF PATIENTS \\
\hline Diabetes & 7 \\
\hline Hypertension & 12 \\
\hline Both diabetes & 4 \\
\hline SHypertension & 6 \\
\hline Renal Fallure & 6 \\
\hline Liver disease & 1 \\
\hline Pulmonary Tuberculosis & 4 \\
\hline Heart Disease & 3 \\
\hline
\end{tabular}
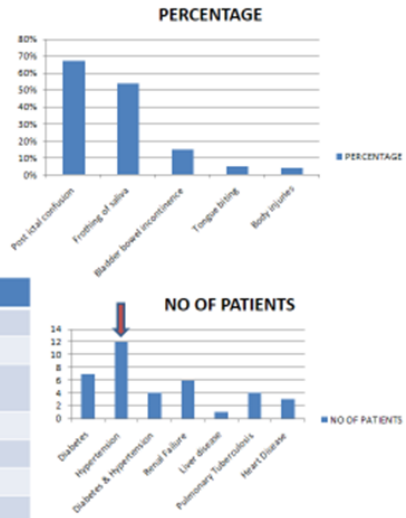

BASED ON METABOLIC ANORMALITY AND EEG

\begin{tabular}{l|l|l|}
\hline $\begin{array}{l}\text { METABOLIC } \\
\text { ABNORMALITY }\end{array}$ & NO OF PATIENTS \\
\hline $\begin{array}{l}\text { Hyperglycemia } \\
\text { Hypoglycemia }\end{array}$ & 8 \\
\hline $\begin{array}{l}\text { Hyponatremia } \\
\text { Hypocalcemia }\end{array}$ & 3 \\
\hline 150 & 114 & 92 \\
\hline $\begin{array}{l}\text { TOTAL } \\
\text { PATIENTS }\end{array}$ & $\begin{array}{l}\text { NO OF } \\
\text { PATIENTS } \\
\text { EEG DONE }\end{array}$ & $\begin{array}{l}\text { NUMBER } \\
\text { OF } \\
\text { ABNORMAL } \\
\text { RECORD }\end{array}$ \\
\hline
\end{tabular}
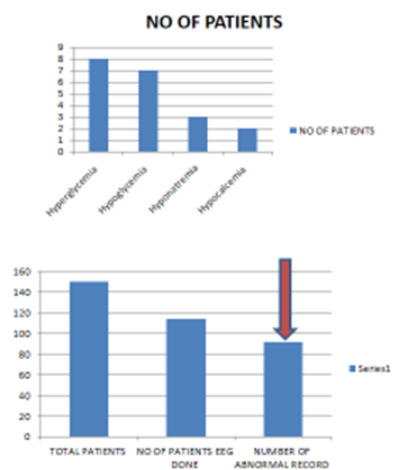

BASED ON CT FINDINGS

\begin{tabular}{|l|l|}
\hline CI FINDINGS & NO \\
\hline $\begin{array}{l}\text { Cortical Venous } \\
\text { Thrombosis }\end{array}$ & $\mathbf{9}$ \\
Intracerebral Hge & 14 \\
\hline $\begin{array}{l}\text { Subarachnoid Hge } \\
\text { Ischaemic Stroke }\end{array}$ & $\mathbf{6}$ \\
\hline $\begin{array}{l}\text { Neurocysticercosis } \\
\text { Tuberculoma }\end{array}$ & $\mathbf{4}$ \\
\hline $\begin{array}{l}\text { PRES } \\
\text { Traumatic Brain } \\
\text { Injury }\end{array}$ & $\mathbf{8}$ \\
\hline Tumour & $\mathbf{2}$ \\
\hline
\end{tabular}

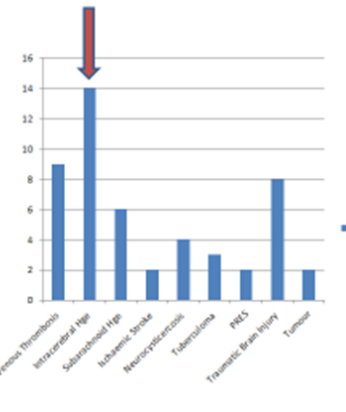

66 GJRA - GLOBAL JOURNAL FOR RESEARCH ANALYSIS 
CONCLUSION

Acute symptomatic seizures were more common in males than females and in $40-60$ years of age. Cerebrovascular diseases were the most frequent cause of acute symptomatic seizures, followed by Acute CNS infections. Eclampsia and cortical venous thrombosis were the common etiology among females. We conclude that the EEG and radiological abnormalities were identified only $60 \%$ of the patients .Rest of the patients found to be metabolic causes.

\section{REFERENCES}

1. Daniel HL. Seizures and epilepsy. In: Kasper DL, Fauci AS, Hauser SL, Longo DL, Jameson JL, Loscalzo J, editors. Harrisons Principles of Internal Medicine. 19th ed., Vol. 2. USA: McGraw Hill Education; 2015. P

2. Chalasani S, Kumar MR. Clinical profile and etiological evaluation of new onset seizures after age 20 years. IOSR J Dent Med Sci 2015; 14:97-101.

3. Frankel MR, Morgenstern LB, Kwiatkowski T, Lu M Tilley BC Broderick JP et $\alpha$ l. Predicting prognosis after stroke: a placebo analysis from the National Institute of Neurological Disorders and Stroke rt-PA Stroke Trial. Neurology. 2000;55:952-959.

4. Muir KW, Weir CJ, Murray GD, Povey C, Lees KR. Comparison of neurological scales and scoring systems for acute stroke 1996;27:1817-1820.

5. Andersen KK, Andersen ZJ, Olsen TS. Predictors of early and late case-fatality in a nationwide Danish study of 26,818 patients with first-ever ischemic stroke. Stroke. 2011;42:2806-2812.

6. Knoflach M, Matosevic B, Rucker M, Furtner M, Mair A, Wille G, et al. Functional recovery after ischemic stroke: a matter of age: data from the Austrian Stroke Unit Registry. Neurology. 2012;78:279-285.

7. Petty GW, Brown RD, Jr, Whisnant JP, Sicks JD, O'Fallon WM, Wiebers DO. Ischemic stroke subtypes : a population-based study of functional outcome, survival, and recurrence. Stroke. 2000;31:1062-1068. 